\title{
Degradation Characteristics of Legume Straw Based Complete Rations in the Rumen Using Nylon Bag Technique
}

\author{
S. Venkateswarlu ${ }^{1 *}$, D. Srinivas Kumar ${ }^{2}$, E. Raghava Rao $^{2}$ \\ ${ }^{1}$ Veterinary Assistant Surgeon, Veterinary Dispensary, Durgi, Guntur (Dt), AP, India \\ ${ }^{2}$ NTR College of Veterinary science, Gannavaram, Krishna (Dt), AP, India
}

\begin{abstract}
A study was conducted to determine the chemical composition and nutrient degradability of legume straw based complete rations using nylon bag technique in buffalo bulls. Two iso-nitrogenous complete rations were prepared by incorporating two legume straws viz. red gram $\left(T_{1}\right)$ and black gram $\left(T_{2}\right)$ and concentrate mixture in 60: 40 proportion. The experiment was conducted using two rumen fistulated buffalo bulls, fed a basal diet comprising of $5 \mathrm{~kg}$ para grass, $4 \mathrm{~kg}$ paddy straw and $1.5 \mathrm{~kg}$ concentrate mixture. Feed samples were incubated in the ventral sac of rumen for 3, 6, 12, 24, 36, 48 and 72hr. In sacco degradation kinetics revealed that rapidly soluble fraction $(a)$, slowly degradable fraction $(b)$, potential degradation $(a+b)$ and effective degradability of $D M, N D F$ and $A D F$ were significantly $(P<0.01)$ higher in $T_{2}$ compared to $T_{1}$. Degradation kinetics of $C P$ revealed that rate constant $(c)$ was higher $(P<0.05)$ in $T_{1}$ while potential degradation $(a+b)$ was higher $(P<0.05)$ in $T_{2}$ compared to other ration. Hence it can be concluded that black gram straw based complete ration have an advantage over red gram straw based complete ration due its higher degradation kinetics of $D M, N D F$ and $A D F$ in the rumen.
\end{abstract}

Key Words: black gram straw, complete diet, in situ degradability, nylon bag, red gram straw

\section{Introduction}

Ruminant animals play a major role in the livelihood of farmers in the developing countries like India. They have a unique ability to utilize roughages. Roughages are bulky feeds that are characterized by being high in fiber and low in energy. A cost effective feeding program can be designed around rations utilizing straw as much or most of the roughage source. Good quality straw can make up $75 \%$ or more of a ruminant diet if supplemented with grain, while a low quality straw might make up only $50 \%$ of diet. Poor quality feed will be consumed at the rate of around $1.25 \%$ of the body weight by the ruminants [1]. Different cereal straws such as wheat straw, paddy straw, barley straw as well as some legume straws like black gram straw, soybean straw, red gram straw have been used in ruminant nutrition depends on their availability. Worldwide total crop residues is estimated to be 3.8 billion metric tons with cereals contributing $74 \%$, sugar crops $10 \%$, legumes $8 \%$, tubers $5 \%$ and oil crops 3\% [2]. Crop residues will provide more than $70 \%$ of the feed resources for Indian livestock by the year 2020 [3].

Legume straw form major roughage source for livestock feeding in costal belt of Andhra Pradesh, in the gram crop growing areas, but due to low nitrogen and high fibre and lignin contents, it cannot meet even the maintenance requirement of ruminants on sole feeding. Feeding of complete feed ensures mixing of required proportion of roughages and concentrate into a uniform blend to supply adequate balanced nutrients, avoid refusal of unpalatable portion of crop residues and enables use of locally available ingredients [4].

Utilization of the straws in complete feed depends on its nutritive value. [5]Stated that nutritive value of ruminant feeds is determined by the concentration of its chemical compositions, as well as rate and extent of digestion in the rumen. Three common methods includingin situ, in vivo and in vitro techniques have been used in order to evaluate the nutritive value of feedstuffs [6]. The nylon bag (in situ) technique provides a powerful tool for the initial evaluation of feedstuffs and for improving our understanding of the processes of degradation which occur within the rumen. It is the more efficient method for measuring rate and extent of digestion in the rumen [7]. Degradation characteristics of straws in the rumen will provide a useful basis for the evaluation of their nutritive value [8]. However, the available information on the nutritive value and rumen degradation kinetics of legume straws based complete ration is scanty. Therefore, a study was undertaken to measure chemical composition and ruminal degradation characteristics of two legume straw based complete rations using in sacco nylon bag technique.

\section{Materials And Methods}

\subsection{Collection, preparation and analysis of samples}

Two locally available legume straws such as red gram straw and black gram straw were procured from fields of farmers and pulverized in hammer mill to have 1 to $2 \mathrm{~cm}$ particle size and used as roughage source. Two iso-nitrogenous complete rations were prepared by using red gram straw $\left(T_{1}\right)$ and black gram straw $\left(T_{2}\right)$ as 
a roughage source and concentrate mixture in 60:40 ratio. The ingredient composition of complete rations was presented in Table 1. Crop residues and complete rations were analyzed for proximate constituents [9] and fibre fractions [10].

\subsection{In sacco degradation procedures}

Two rumen fistulated adult buffalo bulls (Avg. b.wt. $353 \pm 8.26 \mathrm{~kg}$ ) were used for determining in sacco degradation. The animals were fed on standard diet comprising of $4 \mathrm{~kg}$ paddy straw, $5 \mathrm{~kg}$ para grass and $1.5 \mathrm{~kg}$ concentrate mixture to meet the nutrient requirements for maintenance [11].

Approximately $5 \mathrm{~g}$ of ground samples were taken into nylon bags $(30 \mu \mathrm{m}$ in pore size; $13.5 \times 7.5 \mathrm{~cm})$ in duplicate and bags were manually pushed deep in to the liquid phase of ventral sac of rumen and incubated for $3,6,12,24,36,48$ and $72 \mathrm{~h} \mathrm{[12].} \mathrm{After} \mathrm{the} \mathrm{stipulated} \mathrm{incubation} \mathrm{period,} \mathrm{the} \mathrm{bags} \mathrm{were} \mathrm{removed} \mathrm{from} \mathrm{rumen}$ and washed under slow running cold tap water until the rinse water remained clear. Bags were opened and dried at $60-65^{\circ} \mathrm{C}$ for $48 \mathrm{hrs}$ in hot air oven and DM loss during incubation was calculated. To determine the content of water soluble material bags, representing $0 \mathrm{~h}$ degradation also underwent the same washing procedure as the incubated bags. The residue was analyzed for CP, NDF and ADF and disappearance values were calculated for the difference between the nutrient weight before and after incubation of each sample. From the degradability data obtained at different intervals, the constant $\mathrm{a}, \mathrm{b}$ and $\mathrm{c}$ from the expression $\mathrm{P}=\mathrm{a}+\mathrm{b}\left(\mathrm{a}-\mathrm{e}^{-\mathrm{ct}}\right)$ were obtained. Where, "P" is the degradability at time $t$, the constant ' $a$ ' is the instantly degradable fraction, ' $b$ ' is the slowly degradable fraction, ' $a+b$ ' is the potential degradability and ' $c$ ' is the degradation rate or rate constant. The effective degradability was calculated from the expression [12], $\mathrm{P}=\mathrm{a}+\mathrm{bc} / \mathrm{c}+\mathrm{k}$, where ' $\mathrm{k}$ ' is the fractional outflow rate from the rumen, assumed to be $0.05 \mathrm{~h}^{-1}$ in this experiment.

Results of in sacco procedure were statistically analyzed using univariate analysis in SPSS base 17.0 [13] package. Group differences were compared using Duncan's multiple range test[14]

\section{Results And Discussion}

Chemical composition of crop residues and crop residue based complete ratios were presented in Table 2. Two complete rations prepared were iso-nitrogenous with CP range of 13.13-13.73\%. Among the both complete rations black gram straw $\left(\mathrm{T}_{2}\right)$ based complete ration contained less crude fibre, NDF, ADF and lignin and high NFE than red gram straw $\left(\mathrm{T}_{1}\right)$ based complete ration.

Degradation percentages of DM, CP, NDF and ADF at initial incubation times (0-24h) were increased considerably, but increments after $24 \mathrm{~h}$ incubation were slow. Final ( $72 \mathrm{~h}$ incubation) degradation percentage for $\mathrm{DM}, \mathrm{CP}, \mathrm{NDF}$ and $\mathrm{ADF}$ for $\mathrm{T}_{1}$ and $\mathrm{T}_{2}$ were $56.79 \& 64.5,67.86 \& 70.52,40.35 \& 47.45$ and $36.41 \& 43.24$ respectively.Ruminal DM, CP, NDF and ADF degradation characteristics and effective degradability of complete rations are shown in Table 3.

Degradation characteristics rapidly soluble fraction (a fraction) of DM and NDF were significantly higher $(\mathrm{P}<0.01)$ in $\mathrm{T}_{2}$ compared to $\mathrm{T}_{1}$. But no significant difference observed for $\mathrm{CP}$ and ADF. Similar findings were reported in red gram and black gram straw based complete rations [15]. Higher ' $a$ ' fraction in $T_{2}$ might be due to fine dusty particles. Present study black gram straw based complete ration has fine particles than red gram straw based ration. Very fine particles would be rapidly fermented or else washed out of the nylon bag unfermented [16]. Even if the samples were milled in the same mill the difference in small particle proportion depend on the vegetable structure of by products, i.e degree of lignifications and fragility. It is well known that difference between forages in small particles occur during the milling process, even in the same equipment and screen size[17].

The dry matter $\mathrm{b}$ fraction of rations ranged from $26.77-33.05 \%$ which was significantly higher in $\mathrm{T}_{2}$ than $T_{1}$. ' $b$ ' fraction values reported in the present study were lower than that reported[15 \& 18$]$ in total mixed rations. The crude protein $\mathrm{b}$ fraction ranged from 53.87 - 56.09\% no significant difference was observed among the both rations. Crude protein $b$ fraction of complete rations were similar to that reported by [18] but higher than that reported by [15] in red gram straw and black gram straw based complete rations. The NDF and ADF ' $b$ ' fractions were ranged from 32.5 to $35.70 \%$ and 31.71 to $37.60 \%$ respectively. Which were significantly higher in $\mathrm{T}_{2}$ than $\mathrm{T}_{1}$.

Degradation rate (c) of dry matter was not significantly differ between treatments. While NDF $(\mathrm{P}<0.05)$ and $\mathrm{ADF}(\mathrm{P}<0.01)$ degradation rates were significantly higher in $\mathrm{T}_{2}$ than $\mathrm{T}_{1}$. This might be due to lower amount of NDF, ADF and lignin content $\mathrm{T}_{2}$ [19]. Degradation rate of dry matter of complete rations in the present study was faster than crop residues [20] and slower than concentrate feed stuffs [21]. This is possibly due to the fact that fibrous content and degree of lignifications in crop residues were higher than concentrate feedstuffs. This structure is difficult for attachment by microorganisms leading to slow rate of degradation. Degradation rate of crude protein was higher $(\mathrm{P}<0.05)$ in $\mathrm{T}_{1}(0.08)$ compared to $\mathrm{T}_{2}(0.06)$. This might be due to lower amount of maize grain in $\mathrm{T}_{1}$ than $\mathrm{T}_{2}$. Zein protein present in the maize is highly insoluble in naturally 
occurring rumen environment resulting in lower degradation [22]. Degradation rates of DM and CP reported in the present study were corroborated with the findings of [18] for various complete rations.

The Potential degradation $(\mathrm{a}+\mathrm{b})$ of dry matter $(\mathrm{P}<0.01)$ crude protein $(\mathrm{P}<0.05)$, Neutral detergent fibre $(\mathrm{P}<0.01)$ and Acid detergent fibre $(\mathrm{P}<0.01)$ were significantly higher in $\mathrm{T}_{2}$ than $\mathrm{T}_{1}$. Potential degradation of DM, CP for red gram straw and black gram straw based rations were higher than that reported by [15] and lower than that reported by [18] for various total mixed rations.

Effective degradability (ED) was calculated at 0.05 outflow rate per hour. Effective degradability of $\mathrm{DM}, \mathrm{NDF}$ and ADF was significantly $(\mathrm{P}<0.01)$ higher in $\mathrm{T}_{2}$ than $\mathrm{T}_{1}$. Higher degradability of DM in $\mathrm{T}_{2}$ might be attributed to presence of low NDF and ADF content of diet. Because they are negatively correlated with DM degradability [23, 24].No significant difference was observed in CP digestibility. However higher $(\mathrm{P}>0.05)$ effective degradability of CP was observed in $\mathrm{T}_{1}$ (46.3) than $\mathrm{T}_{2}$ (44.9) it might be due to higher proportion of deoiled rice bran in the ration [18] or more maize grain. Zein protein in the maize is highly insoluble in naturally occurring rumen environment [22]. Numerous factors had effect on in sacco degradability, such as bag pore size [25], sample size [26], washing procedures [27], grinding, diet of host animal, species of animal, sample preparation and incubation time [17].

\section{Conclusion}

Based on chemical composition in sacco degradation kinetics it can be concluded that both red gram straw and black gram straw have relatively good nutritive value for ruminants. However, black gram straw based complete ration is better utilized compared to red gram straw based complete rations as evidenced by its higher DM, NDF and ADF degradability and degradation rate in the rumen.

\section{References}

[1]. SaskatchewanMinistry of Agriculture, Straw, a roughage source for ruminants. Production Fact Sheet, Saskatchewan ministry of agriculture.http://www.agriculture.gov.sk.ca/Default. aspx ?DN=13d85902-ba4c-4170-a2c0-7f4486ea031d. 2008.

[2]. R Lal, World crop residues production and implications of its use as a biofuel. Environment International 31, 2005, 575-584.

[3]. K.S. Ramachandra, R.P.Tanejs, K.T.Sampat, U.B.Angadi and S .Anandan, Availability and Requirement of Feeds and Fodders in India. National Institute of Animal Nutrition and Physiology, Bangalore, India 2007.

[4]. R.K. Dhuria, G.R.Purohit and T Sharma, Nutritional evaluation of complete feed containing gram (Cicerarietinum) straw in sheep. Indian Journal of Animal Nutrition 21(2), 2004, 100-103.

[5]. S. Chumpawadee, C. Anut and C. Piyanate,Chemical compositions and nutritional evaluation of energy feeds for ruminant using in vitro gas production technique. Pak. J. Nutr., 6, 2007 607-612.

[6]. N. Maheri-Sis, M. Chamani, A.A. Sadeghi, A. Mirza- Aghazadeh and A. Aghajanzadeh-Golshani, Nutritional evaluation of kabuli and desitype chickpeas (CicerarietinumL.) for ruminants using in vitro gas production technique. Afr. J. Biotechnol., 7, 2008, 2946-2951.

[7]. E.R. Ørskov, F.D. DeBHovell and F. Mould, The use of the nylon bag technique for the evaluation of feedstuffs. Trop. Anim. Prod., 5, 1980, 195-213.

[8]. A.M. Bruno-Soares, J.M.F. Abreu, C.V.M. Guedes and A.A. Dias-da-Silva, Chemical composition, DM and NDF degradation kinetics in rumen of seven legume straws. Anim. Feed Sci. Technol., 83, 2000, 75-80.

[9]. AOAC, Official methods of Analysis (18 ${ }^{\text {th }}$ ed.) Association of Official Analytical chemists, Washington DC, 2007.

[10]. P.J. Van Soest, J.D.Robertson and B.A.Lewis, Methods for dietary fiber, neutral detergent fiber, and non-starch polysaccharides in relation to animal nutrition. Journal of Dairy Science, 74, 1991,3583-3597.

[11]. ICAR, Nutrient requirements of livestock and Poultry. Indian Council of Agricultural Research, New Delhi, 1998

[12]. E.R.Ørskov and I.MacDonald, The estimation of protein degradability in the rumen from the incubation measurements weighted according to rate of passage. Journal of Agricultural Science (Cambridge), 92,1979, 499-503

[13]. SPSS, Statistical packages for Social Sciences, version 17.0, SPSS Inc., Illinois, USA.,2008.

[14]. D.B. Duncan, Multiple range and ' $F$ ' test. Biometrica. 11, 1955, 1-42.

[15]. K Raja Kishore,Evaluation of crop residue based complete rations for augmenting milk and meat production in buffaloes and sheep. Ph.D. thesis submitted to Sri Venkateswara Veterinary University, Tirupati, 2012.

[16]. M.A.G.VonKeyerlingk, M.L.Swift, R.Puchala and J.A. Shelford, Degradability characteristics of dry matter and crude protein of forages in ruminants. Anim.FeedSci.Technol, 57, 1996, 291-311.

[17]. O.M.P. Olivera,Use of in vitro gas production technique to assess the contribution of both soluble and insoluble fractions on the nutritive value of forages. A thesis submitted to the university of Aberdeen, Scotland, in partial fulfillment of the degree of Master of science in Animal Nutrition, 1998.

[18]. S.S. Thakur and S.K.Tomar, Insacco evaluation of total mixed rations. Indian Journal of Animal Nutrition 21 (3), 2004 180-183.

[19]. J. SyamadayalN. Krishna,E. RaghavaRao and T.Janardhan Reddy, Evaluation of complete rations containing urea treated palm press fiber by in vitro and in saccotechniques. Indian Journal of Animal Nutrition 20(3), 2003, 360-364.

[20]. S.Chumpawadee, K.Sommart, T.Vongpralub and V.Pattarajinda,Insacco degradation characteristic of crop residues and selected roughages in Brahman-Thai native crossbred steers. Kasetsart J. (Nat.Sci.) 40, 2006 204-214

[21]. V.B. Woods, F.P.O. Mara and Moloney, The nutritive value of concentrates feedstuffs for ruminant animals. Part I: In situruminal degradability of dry matter and organic matter. Anim. Feed Sci. Technol, 110, 2003. 111-130.

[22]. P.J. McDonald, R.A. Edward,C.A.Morgan and J.F.D. Greenhalgh,Animal Nutrition (6 ${ }^{\text {th }}$ edition, Dorling Kindersley publication, 2002, PP 570-572.

[23]. V.Lopez, D.R. Davies, F.J. Giraldez, M.S.Dhanoa, J.Dijkstra and J.France, Assessment of nutritive value of cereal and legume straws based on chemical composition and in vitrodigestibililty. J.Sci.Food.Agric 85, 2005, 1550-1557.

[24]. B. Prakash, S.S. Rathore, K.C.Das, I.Walling, A.Dhali,D.Medhi, H. Hazarika and C. Rajkhowa, In situ degradability of forest based foliages in mithun. Indian Journal of Animal Nutrition 24(4), 2007, 241-247. 
Degradation characteristics of legume straw based complete rations in the rumen using nylon bag

[25]. E.S. Vanzant, R.C. Cochan and E.V.Titgemeyer. Standardization of in situ techniques for ruminant feed stuffs evaluation. J.Anim.Sci., 76, 1998, 2717-2729.

[26]. J.E. Nocek, Evaluation of specific variables affecting in situ estimates of ruminal dry matter and proteinn digestion. J.Anim.Sci.60, 1985,1347-1358.

[27]. D.J.R.,Cherney,J.A.patterson and R.P.Lemenager Influence of in situ bag rinsing technique on determination of dry matter disappearance. J.Dairy Science. 73, 1990, 391-396

Table 1: Ingredient composition of complete rations fed to buffalo bulls

\begin{tabular}{|l|c|c|}
\hline \multirow{2}{*}{ Ingredients } & \multicolumn{2}{|c|}{ Complete rations } \\
\cline { 2 - 3 } & $\mathbf{T}_{\mathbf{1}}$ & $\mathbf{T}_{\mathbf{2}}$ \\
\hline Red gram straw & 60 & -- \\
\hline Black gram straw & -- & 60 \\
\hline Maize grain & 8.0 & 9.6 \\
\hline DORB & 10.5 & 12.5 \\
\hline Cotton seed cake & 11.6 & 8.8 \\
\hline Gingelly cake & 8.4 & 7.6 \\
\hline Mineral mixture & 1.0 & 1.0 \\
\hline Salt & 0.5 & 0.5 \\
\hline Total & 100 & 100 \\
\hline
\end{tabular}

Table 2: Chemical composition of crop residues and crop residue based complete rations

\begin{tabular}{|c|c|c|c|c|}
\hline Nutrient & Red gram straw & Black gram straw & $\mathbf{T}_{\mathbf{1}}$ & $\mathbf{T}_{\mathbf{2}}$ \\
\hline Dry matter & 93.56 & 91.67 & 93.18 & 92.60 \\
\hline Organic matter & 97.65 & 92.2 & 94.05 & 90.85 \\
\hline Total ash & 2.35 & 7.80 & 5.95 & 9.15 \\
\hline Crude protein & 5.70 & 7.29 & 13.73 & 13.13 \\
\hline Ether extract & 1.51 & 1.23 & 1.33 & 1.14 \\
\hline Crude fibre & 59.95 & 54.03 & 45.18 & 39.56 \\
\hline Nitrogen free extract & 30.49 & 29.66 & 33.81 & 37.02 \\
\hline Neutral Detergent Fibre & 81.98 & 72.56 & 71.13 & 65.29 \\
\hline Acid Detergent Fibre & 72.51 & 66.69 & 50.44 & 47.82 \\
\hline Acid Detergent Lignin & 15.78 & 13.36 & 12.08 & 10.16 \\
\hline Hemi-cellulose & 9.47 & 5.87 & 20.69 & 17.47 \\
\hline Cellulose & 58.2 & 54.6 & 37.19 & 34.5 \\
\hline
\end{tabular}

Table 3 :In sacco degradation characteristics of legume straw based complete rations

\begin{tabular}{|c|c|c|}
\hline Degradation kinetics & $\mathrm{T}_{1}$ & $\mathrm{~T}_{2}$ \\
\hline \multicolumn{3}{|l|}{ DM degradability $(\%)$} \\
\hline$a^{* *}$ & $30.43^{\mathrm{a}}$ & $32.29^{b}$ \\
\hline $\mathrm{b}^{* *}$ & $26.77^{\mathrm{a}}$ & $33.05^{b}$ \\
\hline $\mathrm{C}$ & 0.059 & 0.075 \\
\hline $\mathrm{PD}(\mathrm{a}+\mathrm{b})^{* *}$ & $57.20^{\mathrm{a}}$ & $65.34^{\mathrm{b}}$ \\
\hline $\operatorname{EDDM}(0.05 \%)^{* * *}$ & $43.8^{\mathrm{a}}$ & $51.0^{\mathrm{b}}$ \\
\hline \multicolumn{3}{|l|}{ CP degradability (\%) } \\
\hline $\mathrm{a}$ & 13.26 & 14.88 \\
\hline $\mathrm{b}$ & 53.87 & 56.09 \\
\hline $\mathrm{c}^{*}$ & $0.081^{\mathrm{b}}$ & $0.064^{\mathrm{a}}$ \\
\hline $\mathrm{PD}(\mathrm{a}+\mathrm{b}) *$ & $67.13^{\mathrm{a}}$ & $70.98^{b}$ \\
\hline $\operatorname{EDCP}(0.05 \%)$ & 46.3 & 44.9 \\
\hline \multicolumn{3}{|l|}{ NDF degradability (\%) } \\
\hline $\mathrm{a}^{* *}$ & $9.34^{\mathrm{a}}$ & $13.41^{b}$ \\
\hline $\mathrm{b}^{* * *}$ & $32.51^{\mathrm{a}}$ & $35.70^{\mathrm{b}}$ \\
\hline $\mathrm{c}^{*}$ & $0.04^{\mathrm{a}}$ & $0.06^{\mathrm{b}}$ \\
\hline $\mathrm{PD}(\mathrm{a}+\mathrm{b}) * *$ & $41.85^{\mathrm{a}}$ & $49.11^{b}$ \\
\hline EDNDF $(0.05 \%)^{* *}$ & $24.3^{\mathrm{a}}$ & $31.3^{\mathrm{b}}$ \\
\hline \multicolumn{3}{|l|}{ ADF degradability $(\%)$} \\
\hline $\mathrm{a}$ & 6.68 & 6.44 \\
\hline $\mathrm{b}^{* * *}$ & $31.71^{\mathrm{a}}$ & $37.60^{b}$ \\
\hline $\mathrm{c}^{* *}$ & $0.04^{\mathrm{a}}$ & $0.056^{\mathrm{b}}$ \\
\hline $\mathrm{PD}(\mathrm{a}+\mathrm{b})^{* *}$ & $38.89^{\mathrm{a}}$ & $44.04^{b}$ \\
\hline
\end{tabular}

